\title{
Re: Challenging Non-Traumatic Posterior Urethral Strictures Treated with Urethroplasty: A Preliminary Report
}

\author{
Nicolaas Lumen, Willem Oosterlinck \\ Department of Urology, Ghent University Hospital, Ghent, Belgium
}

Int Braz J Urol. 2009; 35: 442-9

To the Editor,

This interesting paper raises some theories about urethral stricture, its ongoing process, and how to deal with challenging cases. Although only a small number of patients were observed, this fact does not compromise the results, as the incidence of this specific pathology is very low. While urethroplasty was performed on macroscopically healthy ends, there is no histological confirmation of whether the urethral margin tissue is free from fibrosis, which has been suggested by some authors to be one of the most important aspects to be used when performing endto-end anastomosis (1-3).

The authors admit that the hypothesis suggested in their publication lacks both urodynamic and histological studies, which would add supporting data to all of these theories. This lack of supporting data compromises the discussion itself. Histological data should clarify the urethra aspects that suffer from the ischemic effects of radiotherapy, as mentioned above. The confirmation of these findings would justify the use of the prolonged urethral catheter during postoperative period. Moreover, urodynamics studies would confirm the damage of the external sphincter after urethroplasty. If the study had included all these data, it would have had a tremendous impact in the area of urethral stricture, but that is the price to be paid by the pioneers.

The incidence of urethral stricture alone after non-traumatic procedures is very rare, however, the incidence of stenosis combined with rectal fistulas is not uncommon, and consequently there are some publications about this aspect. These publications guide us to some other ways of studying urethral stricture itself, its complications, and reconstruction techniques $(4,5)$.

I congratulate the authors for their initiative in this well described and documented study. With increasing data, histological confirmation of the ischemic tissue, and urodynamics studies, the contribution to urology would be even greater.

\section{REFERENCES}

1. Santucci RA, Joyce GF, Wise M: Male urethral stricture disease. J Urol. 2007; 177: 1667-74.

2. Santucci RA, Mario LA, McAninch JW: Anastomotic urethroplasty for bulbar urethral stricture: analysis of 168 patients. J Urol. 2002; 167: 1715-9.

3. Cavalcanti AG, Costa WS, Baskin LS, McAninch JA, Sampaio FJ: A morphometric analysis of bulbar urethral strictures. BJU Int. 2007; 100: 397-402.

4. Lane BR, Stein DE, Remzi FH, Strong SA, Fazio VW, Angermeier KW: Management of radiotherapy induced rectourethral fistula. J Urol. 2006; 175: 13827; discussion 1387-8.

5. Razi A, Yahyazadeh SR, Gilani MA, Kazemeyni SM: Transanal repair of rectourethral and rectovaginal fistulas. Urol J. 2008; 5: 111-4.

Dr. João P. M. de Carvalho Fluminense Federal University Niteroi, Rio de Janeiro, Brazil E-mail: carvalho.jpm@gmail.com 